\title{
A new mutation in blau syndrome: case report
}

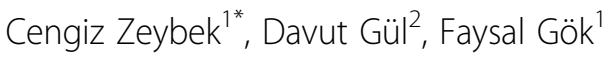 \\ From 21st European Pediatric Rheumatology (PReS) Congress \\ Belgrade, Serbia. 17-21 September 2014
}

\section{Introduction}

Blau syndrome is a rare autoinflamattory granulomatous disease and inherited as autosomal dominant.The classical triad of Blau syndrome is granulomatous dermatitis, symmetric arthritis and recurrent uveitis. However, all of these findings may not be together in the patients. In the majority of patients, the disease is characterized by early onset that usually before 3-4 years of age. The ocular findings of Blau syndrome ocur usuaaly after the articular and skin findings.

\section{Objectives}

Our aim is to describe a new mutation of Blau syndrome here. The defective gen of Blau syndrome is located 16q12.2-13 locus and NOD2 gen is found in this locus. So far, ten NOD2 mutations have been described that causes Blau syndrome. In addition, seven NOD2 mutations have been described that may be associated with Blau syndrome. These mutations are heterozygous state mostly.

\section{Methods}

Five years old male patient had developed papular rash that lasted one year at 5 month old, bilateral knee and ankle arthritis at 4 year old and right anterior uveitis at 5 year old. His papular rush and anterior uveitis was compatible with granulomatous vasculitis and granulomatous uveitis, respectively.

\section{Results}

Blau syndrome gen studies revealed heterozygous missense NOD2 mutation ( P507S [(c.1519C>T)].

\section{Conclusion}

Up to date, 10 Blau-associated genetic mutations have been identified within thisgene, almost in heterozygous state. Two of these mutations (R334Q and R334W)

'Pediatric Rheumatology, Genetics, Gülhane Military Medical Academy, Ankara, Turkey

Full list of author information is available at the end of the article account for more than $50 \%$ of the mutated alleles. The mutation that we found is a new mutation and not described before.

\section{Disclosure of interest}

None declared.

\section{Authors' details}

${ }^{1}$ Pediatric Rheumatology, Genetics, Gülhane Military Medical Academy, Ankara, Turkey. ${ }^{2} \mathrm{TBC}$

Published: 17 September 2014

doi:10.1186/1546-0096-12-S1-P297

Cite this article as: Zeybek et al: A new mutation in blau syndrome: case report. Pediatric Rheumatology 2014 12(Suppl 1):P297.
Submit your next manuscript to BioMed Central and take full advantage of:

- Convenient online submission

- Thorough peer review

- No space constraints or color figure charges

- Immediate publication on acceptance

- Inclusion in PubMed, CAS, Scopus and Google Scholar

- Research which is freely available for redistribution

Submit your manuscript at www.biomedcentral.com/submit
() Biomed Central 